\title{
Study of some toxicological aspects of titanium dioxide nanoparticles through oxidative stress, genotoxicity, and histopathology in tilapia, Oreochromis mossambicus
}

Khurram Shahzad

UO: University of Okara

Muhammad Naeem Khan

University of the Punjab

Farhat Jabeen

Government College University Faisalabad

Abdul Shakoor Chaudhry

Newcastle University Faculty of Science Agriculture and Engineering

Chaman Ara

University of the Punjab

Muhammad Khalil Ahmad Khan

UO: University of Okara

Muhammed Saleem Khan ( $\sim$ SamiiKhan@uo.edu.pk)

University of Okara https://orcid.org/0000-0003-2653-402X

\section{Research Article}

Keywords: Nanoparticle, toxicity, Oreochromis mossambicus, genotoxicity

Posted Date: April 26th, 2021

DOI: https://doi.org/10.21203/rs.3.rs-388947/v1

License: (c) (1) This work is licensed under a Creative Commons Attribution 4.0 International License. Read Full License 
Study of some toxicological aspects of titanium dioxide nanoparticles through oxidative stress, genotoxicity, and histopathology in tilapia, Oreochromis mossambicus

*Corresponding Author: Muhammad Saleem Khan SamiiKhan@uo.edu.pk

Phone: 00923214077320

ORCID: 0000-0003-2653-402X

\section{Abstract}

Extensive use of nanotechnology in multiple commodities is raising concern about nanotoxicity and particularly. Particularly, many studies reported the health hazardous effects of titanium dioxide nanoparticles $\left(\mathrm{TiO}_{2}-\mathrm{NPs}\right)$. Study focuses on toxicity and accumulation of $\mathrm{TiO}_{2}$-NPs in tilapia (Oreochromis mossambicus). For this purpose, Tilapia were kept in water tanks, acclimatized for fourteen days, and treated with different doses of $\mathrm{TiO}_{2}$ nanoparticles $0,0.5$, 1.0, and $1.5 \mathrm{mg} \mathrm{TiO} 2-\mathrm{NPs} / \mathrm{L}$. Results revealed an increase in accumulation of $\mathrm{TiO}_{2}-\mathrm{NPs}$ with an increase in doses. Moreover, with higher dose $(1.5 \mathrm{mg} / \mathrm{L})$ gills had maximum levels compared to muscles and liver tissues whereas other doses showed different accumulation patterns. A significantly higher concentration of catalase, glutathione, and increased necrosis and apoptosis in the liver was also noticed with increasing concentration of $\mathrm{TiO}_{2}$-NPs along with formation of sinusoid spaces and condensed nuclear bodies. Elevated values of olive tail movement and \% tail DNA were also noticed with increased concentration of $\mathrm{TiO}_{2}-\mathrm{NPs}$. This study concluded that $\mathrm{TiO}_{2}-\mathrm{NPs}$ produced oxidative stress by accumulation in soft tissues and induced pathology and genotoxicity.

Keywords: Nanoparticle; toxicity; Oreochromis mossambicus; genotoxicity

\section{Introduction}

The structure dimensions of nanoparticles range from 1-100 nm and exist on earth for millions of years for the use of mankind (Asghar et al. 2016; Masciangioli and Zhang 2003). These particles are being engineered for various applications in industries such as drug delivery systems, chemical sensors, biosensors, optics, textiles, medical devices, electronics, and environmental remediation (Khan et al. 2015b; Khan et al. 2017a; Raza et al. 2017). However, extensive use is also responsible for aquatic habitat penetration and raising concerns of ecotoxicology (Khan et al. 2015b; Ramsden et al. 2013). The most prominent sources of these nanoparticles are colloids found in natural waters, soil, and sediments. Volcanic dust in the atmosphere is also an important source of $\mathrm{TiO}_{2}$-NPs (Buffle, 2006 and Handy, 
tissues of aquatic animals than the normal permissible concentrations (Asghar et al. 2015; Khan et al. 2018; Khan et al. 2020).

$\mathrm{TiO}_{2}$-NPs are most extensively applicable in dyes, makeups items and sunscreens (Hao et al. 2009; Shakeel et al. 2016) and released in the natural environment through wastewater effluents where they cause gill injury, oxidative stress, changes in hematology, and plasma ion imbalance (Asghar et al. 2018; Rocco et al. 2015; Shakeel et al. 2018). Further, these NPs mostly penetrate via the skin, gills, and gastrointestinal absorption to blood and liver (Shakeel et al. 2018; Shakeel et al. 2016). therefore, the main targets to study the effect of nanoparticle exposure are gills, liver, brain, gut, and muscles (Khan et al. 2017b).

Some previous work on $\mathrm{TiO}_{2}$-NPs toxicity showed that it produced oxidative stress and gill injury in exposed zebrafish (Griffitt et al. 2009; Tang et al. 2019). Zhu et al. (2008) also demonstrated oxidative stress caused by $\mathrm{TiO}_{2}$ NPs with an increasing trend from lower to higher levels of dose at the developmental stage of Zebrafish (Danio rerio) larvae. The genotoxic potential of $\mathrm{TiO}_{2}$-NPs has been assessed primarily through DNA breakage (Nigro et al. 2015). A significant $\mathrm{TiO}_{2}$-NPs genotoxic effect on DNA damage was reported in zebrafish model (Rocco et al. 2015).

This study focuses on the toxicological assessment of engineered $\mathrm{TiO}_{2}-\mathrm{NPs}$ in tilapia (Oreochromis mossambicus). The sub-lethal toxicological effects examined include bioaccumulation, genotoxicity, oxidative stress and histological alterations.

\section{Materials and Methods}

\section{Characterization}

TIO 2-NPs (Sigma-Aldrich, GmbH, Germany) $<100 \mathrm{~nm}$ with 99 percent purification were in the form of nanopowder. The surface area was analyzed through scanning electron microscope (Philips, ESEM XL30). Figure 1 exhibits a spherical shape and fits the size of the nanoscale with an average of $72+12.50 \mathrm{~nm}$. The photograph is taken with the magnification of 20000 and 65000 with a power source of $20 \mathrm{kV}$.

\section{Model animal collection and acclimatization}

With ethical permission, fish (weight $50.90 \pm 0.37 \mathrm{~g} ; 7.38 \pm 0.19 \mathrm{~cm}$ length) was collected from aquaculture ponds in Patoki City, Kasur District, Pakistan. The transportation to lab was carried out in plastic bags of freshwater with continuous oxygen through the oxygen-carrying cylinder to minimize the transport stress. Before treatment, the fish were acclimatized to glass tanks environment for fourteen days.

Experiment Design

The fish were grouped in four with three replicates per group in 12 experimental water glass tanks ( 5 fish/aquaria). Each aquarium has dimensions of $45.72 \times 60.96 \times 45.72 \mathrm{~cm}$ with 40 liters of water. Fish were provided commercial feed consisting of crude protein (35\%), fat (4\%), fiber (5\%) with $12 \%$ average moisture. The feed was provided twice a day at morning and evening hours.

TiO2-NPs solution (Stock solution) was prepared in Milliquat water for treatment, sonicated for 30 minutes at $35 \mathrm{kHz}$ (WUC-A06H). Four doses included T0 $(0 \mathrm{mg} / \mathrm{L}), \mathrm{T} 1(0.5 \mathrm{mg} / \mathrm{L}), \mathrm{T} 2(1.0 \mathrm{mg} / \mathrm{L})$, and T3 $(1.5 \mathrm{mg} / \mathrm{L})$ were prepared for the treatment. The exposure of TiO2-NPs did not feed the fish to reduce the nanoparticle attachment in the food. Water from each aquarium was changed 24 hours and drain through suction pumps remaining $20 \%$ water. The suction pumps also removed the animal waste. Then, fresh water was added to each aquarium. 
On the $14^{\text {th }}$ day, fish were carried in a small water container to take the samples. 3 to 4 drops of clove oil were used to anesthetize the fish. Blood samples were obtained from the dorsal aorta in EDTA vials using BD syringes.

79 Then, Fish were dissected form liver, kidney, and muscle samples. For biochemical and oxidative stress-enzymatic and non-enzymatic analysis, samples were preserved in plastic bottles and stored at $-20^{\circ} \mathrm{C}$. The tissues for histological analysis were put in Bouin's fixative.

$83 \mathrm{pH}$ meter (Velp Germany) was used for $\mathrm{pH}$ measurement. Conductivity, dissolved oxygen (DO) and temperature 84 meter multi-function meter (JENCO, Model 3173R) respectively. p-alkalinity, absolute alkalinity, CE resilience, maximum hardness, and chlorides was measured with APHA (2005).

p-Alkalinity

took Water sample $(25 \mathrm{ml})$ in conical flask with 2 drops of phenolphthalein. $\mathrm{H}_{2} \mathrm{SO}_{4}(0.02 \mathrm{~N})$ was used and the sample

\section{Total alkalinity}

$$
\mathrm{p}-\text { Alkalinity }=\frac{\mathrm{ml} \mathrm{H} 2 \mathrm{SO} 4 \text { used } \times 1000}{\text { water sample }(\mathrm{ml})}
$$

Mixed indicator with 2 drops of $0.02 \mathrm{~N} \mathrm{H} 2 \mathrm{SO} 4$ titrated sample and titrated it until the bricks red color.

$$
\text { Total Alkalinity }=\frac{\mathrm{ml} \mathrm{H} 2 \mathrm{SO} 4 \text { used } \mathrm{x} 1000}{\text { water sample }(\mathrm{ml})}
$$

Ca-hardness

For Calcium hardness, $25 \mathrm{ml}$ of water sampled was taken and added $1 \mathrm{ml}$ of NOH to produce $\mathrm{pH} 12$ to 13 . Then

\section{Total hardness}

$25 \mathrm{ml}$ water sample was diluted with distilled water to make a volume of $100 \mathrm{ml}$ in flask. The $\mathrm{pH}$ of the sample was

\section{Chlorides}

$$
\mathrm{Ca}-\text { Hardness }=\frac{\text { ml EDTA } \times 1000}{\text { water sample }(\mathrm{ml})}
$$

$1 \mathrm{ml} \mathrm{K2} 2 \mathrm{CrO} 4$ was added as an indicator in $25 \mathrm{ml}$ sample. This solution is titrated with $\mathrm{AgNO}_{3}$ till light red color. The results were expressed as $\mathrm{mg} / \mathrm{l}$.

\section{Inductively Coupled Plasma Mass Spectrometry of Sample}

$1121 \mathrm{~g}$ of frozen sample was mixed with $10 \mathrm{ml}$ of $\mathrm{HNO} 3$ and $2 \mathrm{ml}$ of pyruchloric acid (HClO4) to digest the sample. Then 
114 digested sample was diluted with cold up to $50 \mathrm{ml}$, filtered (Whatman) analyzed using plasma mass spectrometry

115 (APHA, 2005).

116 Biochemical Assay

117 For this assay, gills and liver samples were used. First both samples processed through Teflon tissue homogenizer for

118 homogenate preparation. The samples were first washed with buffer, and then immersed in $10 \% 0.1 \mathrm{M}$ phosphate

119 buffer ( $\mathrm{pH} 7.4)$, centrifuged at $4^{\circ} \mathrm{C}$ for $10 \mathrm{~min}$ at $5000 \mathrm{rpm}$ and superintendents stored in a freezer.

120 lipid peroxidation Estimation

121 LPO estimation was done through thiobarbituric acid reactive substances synthesis in homogenate liver and gills

122 samples as (MDA) equivalents. Buege and Aust (1978) was followed for this LPO estimation

123 Catalase activity

124 CAT activities were assessed using the protocol of Claiborne (1985). Mixture for this estimation was a solution of 3 $125 \mathrm{ml}$ volume and consisted of $100 \mu \mathrm{l}$ sample, $1.90 \mathrm{ml}$ potassium phosphate buffer $(50 \mathrm{mM}, \mathrm{pH} 7.0)$. The reaction was 126 initiated by $1 \mathrm{ml}$ of $\mathrm{H}_{2} \mathrm{O}_{2}$ and read through a spectrophotometer at $240 \mathrm{~nm}$ with an interval of 30 seconds for 3 minutes.

127 Superoxide dismutase activity

128 Estimation of enzyme activities was done by Marklund and Marklund (1974) protocol and based on the ability of SOD 129 to inhibit the auto-oxidation of pyrogallol. A mixture of sample and $2.80 \mathrm{ml} \mathrm{K}_{2} \mathrm{PO}_{4}$ buffets $(0.05 \mathrm{M}, \mathrm{pH} 8.2)$ incubated 130 at $20^{\circ} \mathrm{C}$ for $20 \mathrm{~min}$ was used for this assay. This reaction was started with $100 \mu \mathrm{l}$ of 8 ampigravalol. The abosrance 131 of the solution mixture was measured at $412 \mathrm{~nm}$ for $3 \mathrm{~min}$ with a 30 seconds interval and represented as per milligram 132 of protein.

\section{Glutathione}

Estimation was done through Jollow et al. (1974). Homogenate and sulfanilic acid were taken in equal amounts, mixed well and then incubation was done at $4^{\circ} \mathrm{C}$ for an hour. Centrifugation of this mixture was carried out at 12,000 rpm for 15 minutes. Then, mixed $0.4 \mathrm{ml}$ supernatant with $2.2 \mathrm{ml}$ of $0.1 \mathrm{M} \mathrm{K}_{2} \mathrm{SO}_{4}$ buffer $(\mathrm{pH} 7.4)$ initiated the reaction with $0.4 \mathrm{ml}$ of DTNB (5.5 + -dithiobis-2-nitrobenzoic acid). Finally, the absorbance was recorded at $412 \mathrm{~nm}$ within 30 seconds of reaction initiation.

140 The liver and gills samples were processed through Humason (1979) for histological studies.

141 Comet Assay

142 Protocol of Singh et al. (1988) for comet assay was adopted and slide preparation. The staining of slides were done 143 with ethidium bromide for examination under fluorescence microscope at 400X. Comet IV a Computer Software was 144 used for scoring the comet (Chaubey, 2005).

145 Statistical analysis

146 Raw data for all studied parameters were recorded separately. Minitab (V. 17) was the computer package used for 147 processing of data. Comparison was made through Tukey's test at 95\% level and ANOVA to compare significance of 148 means of each parameter.

149 Results

150 Physicochemical analysis

151 Different physicochemical parameters (temperature, TDS, alkalinity, total hardness, Ca-hardness, total alkalinity, and 152 chlorides are listed in Table 1. 
154 Table 1: Showing accumulation of $\mathrm{Ti}(\mu \mathrm{g} / \mathrm{Kg})$ in the tissues of tilapia (Oreochromis mossambicus).

155

\begin{tabular}{|c|c|c|c|c|}
\hline \multirow[t]{2}{*}{ Tissues } & \multicolumn{4}{|c|}{ Treatments } \\
\hline & $\mathrm{T}_{0}(0 \mathrm{mg} / \mathrm{L})$ & $\mathrm{T}_{1}(0.5 \mathrm{mg} / \mathrm{L})$ & $\mathrm{T}_{2}(1.0 \mathrm{mg} / \mathrm{L})$ & $\mathrm{T}_{3}(1.5 \mathrm{mg} / \mathrm{L})$ \\
\hline Gills & $0.07 \pm 0.01^{\mathrm{d}}$ & $0.46 \pm 0.00577^{\mathrm{g}}$ & $0.71 \pm 0.01^{\mathrm{d}}$ & $4.29 \pm 0.02^{\mathrm{a}}$ \\
\hline Liver & $0.093 \pm 0.02^{\mathrm{c}}$ & $0.41 \pm 0.0153^{\mathrm{g}}$ & $0.62 \pm 0.02^{\mathrm{f}}$ & $4.13 \pm 0.02^{\mathrm{a}}$ \\
\hline Muscles & $0.42 \pm 0.02^{\mathrm{d}}$ & $0.65 \pm 0.0153^{\mathrm{e}}$ & $3.91 \pm 0.02^{\mathrm{b}}$ & $3.97 \pm 0.4^{\mathrm{b}}$ \\
\hline
\end{tabular}

157 All values described as mean $\pm \mathrm{SD}(p<0.05)$

158 Accumulation of $\mathrm{TiO} 2$ from $\mathrm{TiO}_{2}$-NPs

159 With increasing doses, Ti started to accumulate in the tissues. Gills accumulated maximum compared to liver and

160 muscles tissues. The concentration of Ti accumulation was $4.29 \pm 0.02 \mu \mathrm{g} / \mathrm{g}$ in gills at $1.5 \mathrm{mg} / \mathrm{L}$ dose. At a higher dose,

161 the mean Ti concentration was $24.13 \pm 0.02 \mu \mathrm{g} / \mathrm{g}$ and $3.97 \pm 0.4 \mu \mathrm{g} / \mathrm{g}$ in the liver and muscles. The order of

162 concentration was gills $>$ liver $>$ muscles.

163 Oxidative Stress assay

164 With increasing dose, elevated activities of liver SOD were recorded in treated fish. In the control group, the

165 value of CAT in the liver and gills was $6.73 \pm 0.056 \mathrm{U} / \mathrm{mg}$ and $6.53 \pm 0.058 \mathrm{U} / \mathrm{mg}$ respectively. While mean values

166 CAT in liver and gills on the higher doses were $5.87 \pm 0.15 \mathrm{U} / \mathrm{mg}$ and $11.40 \pm 1.20 \mathrm{U} / \mathrm{mg}$ respectively. Fluctuation in

167 the level of glutathione (GSH), increase in gills, and decrease in the liver, was also recorded with increasing $\mathrm{TiO}_{2}-$

168 NPs concentration. GSH value in liver and gills was $3.77 \pm 0.058 \mathrm{U} / \mathrm{mg}$ and $2.13 \pm 0.15 \mathrm{U} / \mathrm{mg}$ respectively in the

169 control group and $1.6333 \pm 0.1528 \mathrm{U} / \mathrm{mg}$ and $3.3667 \pm 0.1528 \mathrm{U} / \mathrm{mg}$ in the liver and gills at a higher dose. $\mathrm{TiO}_{2}-\mathrm{NPs}$

170 also raise the level of LPO (lipid peroxidation) in gills (Table 2).

171 GST showed different results, it was recorded higher in the treated group 2, GST in the liver $(0.15 \mathrm{~mol} / \mathrm{mg}$ 172 prot) significantly $(\mathrm{P} \leq 0.05)$ was higher than gills, kidneys, and heart. In treated group 2 , GSH $(130.0 \mu \mathrm{mol} / \mathrm{mg}$ tissue $)$

173 was high in gills and kidneys compared to other organs.

174 Table 2: Showing the oxidative and anti-oxidative enzymes estimation

175

\begin{tabular}{cccccc}
\hline Enzymes & Tissues & \multicolumn{4}{c}{ Treatments } \\
\hline \multirow{2}{*}{ CAT U/mg } & & $\mathrm{T}_{0}(0 \mathrm{mg} / \mathrm{L})$ & $\mathrm{T}_{1}(0.5 \mathrm{mg} / \mathrm{L})$ & $\mathrm{T}_{2}(1.0 \mathrm{mg} / \mathrm{L})$ & $\mathrm{T}_{3}(1.5 \mathrm{mg} / \mathrm{L})$ \\
\cline { 2 - 6 } & Gills & $6.53 \pm 0.058^{\mathrm{d}}$ & $7.7667 \pm 0.1155^{\mathrm{c}}$ & $9.5667 \pm 0.1155^{\mathrm{b}}$ & $11.40 \pm 1.20^{\mathrm{a}}$ \\
& Liver & $6.73 \pm 0.058^{\mathrm{d}}$ & $6.133 \pm 0.1528^{\mathrm{e}}$ & $5.7667 \pm 0.1528^{\mathrm{e}}$ & $5.87 \pm 0.15^{\mathrm{e}}$ \\
\hline \multirow{2}{*}{ SOD U/mg } & Gills & $7.43 \pm 0.1528^{\mathrm{h}}$ & $9.733 \pm 0.1528^{\mathrm{f}}$ & $11.333 \pm 0.153^{\mathrm{d}}$ & $13.733 \pm 0.153^{\mathrm{b}}$ \\
& Liver & $8.8667 \pm 0.0577^{\mathrm{g}}$ & $10.467 \pm 0.115^{\mathrm{e}}$ & $12.133 \pm 0.153^{\mathrm{c}}$ & $14.867 \pm 0.153^{\mathrm{a}}$ \\
\hline \multirow{2}{*}{ GSH U/mg } & Gills & $2.13 \pm 0.15^{\mathrm{e}}$ & $2.833 \pm 0.1155^{\mathrm{c}}$ & $3.1333 \pm 0.1528^{\mathrm{bc}}$ & $3.3667 \pm 0.1528^{\mathrm{b}}$ \\
& Liver & $3.77 \pm 0.058^{\mathrm{a}}$ & $2.667 \pm 0.1528^{\mathrm{d}}$ & $1.8667 \pm 0.1528^{\mathrm{ef}}$ & $1.6333 \pm 0.1528^{\mathrm{f}}$ \\
\hline \multirow{2}{*}{ LPO nmol/mg } & Gills & $2.033 \pm 0.1528^{\mathrm{d}}$ & $3.4667 \pm 0.1528^{\mathrm{c}}$ & $3.8667 \pm 0.0577^{\mathrm{b}}$ & $5.7667 \pm 0.1155^{\mathrm{a}}$ \\
& Liver & $1.1667 \pm 0.1528^{\mathrm{f}}$ & $1.440 \pm 0.0200^{\mathrm{ef}}$ & $1.5233 \pm 0.0208^{\mathrm{e}}$ & $1.6000 \pm 0.0265^{\mathrm{e}}$ \\
\hline
\end{tabular}


All values are mean \pm S.D $(p<0.05)$

Histology

$\mathrm{TiO}_{2}$-NPs induced histological alterations gills are shown in Fig.2. Fig.2 (a) shows reference control, while Fig.2 (b) to (d) indicates treated with $\mathrm{TiO}_{2}$ nanoparticles. Fig.2 (a) expresses the normal arrangement of gill lamellae. Whereas, in reference treated with $\mathrm{TiO}_{2}$ nanoparticles gills undergo hyperplasia, rupturing of gill filaments, gill lamellae fusion, and primary and secondary gill lamellae thickening.

The liver histology of reference treated with $\mathrm{TiO}_{2}$ nanoparticles shows alterations in hepatic cells. Fig.3. (a) indicates liver histology of reference control whereas, Fig.3. (c) to (d) indicates apoptosis and necrosis characterized by the presence of sinusoid spaces and condensed nuclear bodies.

Comet Assay

In order to check the $\mathrm{TiO}_{2}$-NPs potential genotoxicity and its role in damaging the DNA molecules of fish erythrocytes, an alkaline comet assay was used (Fig.4). Increased DNA damage was observed with increased concentration of $\mathrm{TiO}_{2}-\mathrm{NPs}$ exposure. \% Tail DNA in the control sample was $4.699 \pm 1.955$ that significantly increased in samples treated with a high dose of $\mathrm{TiO}_{2}$-NPs $(18.219 \pm 0.581)$. $\mathrm{T}_{2}(1.0 \mathrm{mg} / \mathrm{L})$ and $\mathrm{T}_{3}(1.5 \mathrm{mg} / \mathrm{L})$ did not show any significant difference in $\%$ tail DNA. Similarly, increased dose concentration of $\mathrm{TiO}_{2}$-NPs also elevates the level of olive tail movement. Olive tail movement in the control sample was $0.331 \pm 0.053$, which was much lower than samples treated with $\mathrm{TiO}_{2}-\mathrm{NPs} 7.472 \pm 1.249$ during $\mathrm{T}_{3}(1.5 \mathrm{mg} / \mathrm{L})$ (Fig. $5 \mathrm{a} \mathrm{b}$ ).

\section{Discussion}

Certain studies on the accumulation of nanomaterials in living tissues and their toxic effects have already been conducted. Ates et al. (2013) examined nanoparticle accumulation in different tissues of goldfish (Carassius auratus) and detected the highest accumulation in gills. Results were opposite to our research where the highest accumulation of Ti was observed in liver tissues. In a study on freshwater mussels, increased accumulation of heavy metal was noticed in soft tissues of mussels on increasing the dose of heavy metals (Sohail et al. 2016).

Lipid peroxidation is strongly associated with ROS. It produces free radicals in cellular membranes and starts the oxidation of unsaturated fatty acids. Damage to biomolecules, including DNA and proteins is destructive for lipid peroxidation at cellular or organ level (Asghar et al. 2017; Khan et al. 2015a; Khan et al. 2016; Wilhelm 1990). Membrane damage is due to an increased level of LPO as a result of oxygen reactive species ROS formation (Asghar et al. 2017). Polyunsaturated fatty acids, an important constituent of biomembranes, are highly vulnerable to peroxidation. Zhu et al. (2008) explained the impact of $\mathrm{C}_{60}$ on the LPO level of fathead minnow. The final results of the study suggest an increase in LPO in the brain, liver, and gills of fathead minnow. In another study by Hao et al. (2009) effect of $\mathrm{TiO}_{2}$-NPs on the LPO level of different tissues of juvenile crap was determined. The final results of the study suggest a comparatively high level of LPO in the liver than gills. This result is opposite to our study which indicates an elevated level of LPO in the gills rather than the liver.

Further, Hamid et al. (2016) studied the role of superoxide dismutase (SOD) in regulating the concentration of superoxide radical $\left(\mathrm{O}_{2}^{-}\right)$at the cellular level. SOD converting superoxide radical into $\mathrm{H}_{2} \mathrm{O}_{2}$; ultimately lowers its concentration. $\mathrm{H}_{2} \mathrm{O}_{2}$ resists the activities of different enzymes by penetrating biomembranes and is further catabolized by the CAT enzyme. Xiong et al. (2011) correlates raised CAT activity, in zebrafish gills, with $\mathrm{TiO}_{2}-\mathrm{NPs}$ 
accumulation. In a study on juvenile craps, a direct association was noticed between dose and the liver's SOD activity.

214 In contrary to this an indirect association was observed between SOD activity and increased dose concentration in gills (Hao et al. 2009). Similarly, our study also supports raised SOD levels in the liver.

The present study highlights maximum GSH level in the gills. Whereas, a decrease in GSH activity of the liver was reported. Smith et al. (2007) also reported parallel results while working on the treatment of rainbow trout with single-walled carbon nanotubes. They examined decreased GSH activity in liver tissues of rainbow trout. Ramsden et al. (2013) in another study treat embryos of zebrafish with nanoparticles of $\mathrm{TiO}_{2}$ and noted elevated levels of GSH in liver tissues. GSH plays a crucial role in cell protection from the highly reactive hydroxyl group. GSH reduces the hydroxyl group and because of this oxidative stress mediating property of GSH, it becomes essential to regulate the level of antioxidant and oxidative enzymes (Ahmad et al. 2019; Hamid et al. 2016; Khan et al. 2016).

Gills being direct contact with the aquatic environment are considered the primary site for gaseous exchange (Guan and Lin 2004). This explained that the osmoregulatory functions of fish were disturbed and it was in severe stress. Different hepatic alterations, specifically liver cell apoptosis, are also caused by $\mathrm{TiO}_{2}-\mathrm{NPs}$ (Rahman et al. 2002). To determine the possible association between hepatic apoptosis and $\mathrm{TiO}_{2}-\mathrm{NPs}$, liver tissues of fish were exposed to titanium dioxide. Smith et al. (2007) in their study observed the same hepatic apoptotic phenomenon. In another study by Hao et al. (2009) on juvenile carp same results were reported.

$\mathrm{TiO}_{2}$-NPs role in damaging the erythrocytes of fish (O. mossambicus) has been proved by comet assay. Increased exposure to elevated $\mathrm{TiO}_{2}$-NPs concentration significantly raises the level of olive tail movement and $\%$ tail DNA. Maximum genotoxic action of $\mathrm{TiO}_{2}$-NPs was observed during the $14^{\text {th }}$ day of study at an increased dose concentration of $\mathrm{T}_{3}(1.5 \mathrm{mg} / \mathrm{L})$. Vignardi et al. (2015) studied the genotoxic activities of nano $\mathrm{TiO}_{2}$ in $\mathrm{mTrachinotus}$ carolinus; a marine fish and reported similar results. Shakeel et al. (2018) demonstrated the increased toxicity of bulk $\mathrm{TiO}_{2}$, in marine mussel's (Mytilus galloprovincialis) hemocytes. This study also detected the genotoxic effects of $\mathrm{TiO}_{2}$ and its role in damaging the DNA molecule. A previous study contradicts our results and reports lower level damage to DNA at increased dose concentration (Sohail et al. 2016). In an experiment on European sea bass (Dicetrarchus labrax), showed that $\mathrm{TiO}_{2}-\mathrm{NPs}$ have more potential of inducing genotoxicity (Nigro et al. 2015). Effect of $\mathrm{TiO}_{2}$-NPs elevated dose concentration in zebrafish (Danio rerio) is also examined in a study that inferred the role of $\mathrm{TiO}_{2}$-NPs in DNA damage and apoptosis (Rocco et al. 2015).

241 Lethal and toxic effects of $\mathrm{TiO}_{2}$ nanoparticles, on tilapia (O. mossambicus), are examined in this study. $\mathrm{TiO}_{2}-\mathrm{NPs}$

242 exposure within the range of $0.5-1.5 \mathrm{mg} / \mathrm{L}$ is not lethal to the tilapia. Because of this reason variety of changes were 243 observed during this experiment. The liver shows the highest vulnerability to Ti toxicity during $\mathrm{TiO}_{2}-\mathrm{NPs}$ exposure. Increased accumulation of $\mathrm{Ti}$ in liver tissues results in elevated LPO level, decrease in the antioxidant enzyme, and pathological modifications in tissues. Titanium dioxide also results in RBCs genotoxicity of fish which ultimately leads to different abnormalities including olive tail movement or \%tail breakage.

\section{Declarations}

249 Approval was taken from ethical review board of the University before start of the study. 


\section{Consent for publication}

251 Not applicable.

252 Availability of data and material

253 Not applicable.

254 Competing interests

255 The authors declare that they have no competing interests.

256 Funding

257 This study does not receive any grants or funds.

258 Authors' contributions

259 KS, MNK, and FJ analyzed, interpreted, and formatted the data. ASC, CA, MKAK, and MSK performed the 260 histopathology and genotoxicity examination and write the manuscript. The final manuscript was read and approved 261 by all authors.

262 References

263 Ahmad S, Gull M, Shah A, Khan FU, Rafiq M, Lutfullah G, Khan AZ, Amin F, Azhar N, Khan MS (2019) Antimicrobial, Antioxidant and Cytotoxic Potential of Aerial Parts of Monotheca buxifolia J math fundam Sci 51:138-151

Asghar MS, Khan MS, Aziz N, Qurashi FJ, Wajid M, Farooq Z (2017) Antioxidant potential of Allium sativum, Cinnamomum zeylanicum and Azadirachta indica against free radicals and their antimicrobial activity against isolated microbes from diseased Tilapia J Entomol Zool

Asghar MS, Quershi NA, Jabeen F, Shakeel M, Khan M (2016) Genotoxicity and oxidative stress analysis in the Catla catla treated with ZnO NPs J Bio Environ Sci 8:91-104

Asghar MS, Qureshi NA, Jabeen F, Khan MS, Shakeel M, Chaudhry AS (2018) Ameliorative effects of Selenium in $\mathrm{ZnO}$ NP-induced oxidative stress and hematological alterations in Catla catla Biol Trace Elem Res 186:279-287

Asghar MS, Qureshi NA, Jabeen F, Khan MS, Shakeel M, Noureen A (2015) Toxicity of zinc nanoparticles in fish: a critical review J Bio Environ Sci 7:431-439

Ates M, Demir V, Adiguzel R, Arslan Z (2013) Bioaccumulation, subacute toxicity, and tissue distribution of engineered titanium dioxide nanoparticles in goldfish (Carassius auratus) J Nanomater 2013

278 Buege JA, Aust SD (1978) Microsomal lipid peroxidation. In: Methods in enzymology, vol 52. Elsevier, pp 302310

Claiborne A (1985) Handbook of methods for oxygen radical research. J Florida: CRC Press, Boca Raton,

Griffitt RJ, Hyndman K, Denslow ND, Barber DS (2009) Comparison of molecular and histological changes in zebrafish gills exposed to metallic nanoparticles Toxicol Sci 107:404-415

283 Guan H, Lin Y (2004) Constitution and the tolerance of several heavy metals on the gill tissue of carp Chinese Journal of Fisheries 17:68-72 
Hamid A, Khan MU, Yaqoob J, Umar A, Rehman A, Javed S, Sohail A, Anwar A, Khan M, Ali A (2016) Assessment of mercury load in river Ravi, urban sewage streams of Lahore Pakistan and its impact on the oxidative stress of exposed fish J Bio Environ Sci 8:63-72

Hao L, Wang Z, Xing B (2009) Effect of sub-acute exposure to TiO2 nanoparticles on oxidative stress and histopathological changes in Juvenile Carp (Cyprinus carpio) J Environ Sci 21:1459-1466

Jollow D, Mitchell J, Zampaglione N, Gillette JJP (1974) Bromobenzene-induced liver necrosis. Protective role of glutathione and evidence for 3, 4-bromobenzene oxide as the hepatotoxic metabolite 11:151-169

Khan MS, Jabeen F, Asghar MS, Qureshi N, Shakeel M, Noureen A, Shabbir S (2015a) Role of nao-ceria in the amelioration of oxidative stress: current and future applications in medicine Int J Biosci 6:89-109

Khan MS, Jabeen F, Qureshi NA, Asghar MS, Shakeel M, Noureen A (2015b) Toxicity of silver nanoparticles in fish: a critical review J Bio Environ Sci 6:211-227

Khan MS, Qureshi NA, Jabeen F (2017a) Assessment of toxicity in fresh water fish Labeo rohita treated with silver nanoparticles Appl Nanosci 7:167-179

Khan MS, Qureshi NA, Jabeen F (2018) Ameliorative role of nano-ceria against amine coated Ag-NP induced toxicity in Labeo rohita Appl Nanosci 8:323-337

Khan MS, Qureshi NA, Jabeen F, Asghar MS, Shakeel M, Fakhar-e-Alam M (2017b) Eco-friendly synthesis of silver nanoparticles through economical methods and assessment of toxicity through oxidative stress analysis in the Labeo Rohita Biol Trace Elem Res 176:416-428

Khan MS, Qureshi NA, Jabeen F, Wajid M, Sabri S, Shakir M (2020) The role of garlic oil in the amelioration of oxidative stress and tissue damage in rohu Labeo rohita treated with silver nanoparticles Fisheries Sci:1-15

Khan MU, Qurashi NA, Khan MS, Jabeen F, Umar A, Yaqoob J, Wajid M (2016) Generation of reactive oxygen species and their impact on the health related parameters: A critical review Int J Biosci 9:303-323

Marklund S, Marklund GJEjob (1974) Involvement of the superoxide anion radical in the autoxidation of pyrogallol and a convenient assay for superoxide dismutase Eur J Biochem 47:469-474

Masciangioli T, Zhang W-X (2003) Peer reviewed: environmental technologies at the nanoscale. ACS Publications, Nigro M, Bernardeschi M, Costagliola D, Della Torre C, Frenzilli G, Guidi P, Lucchesi P, Mottola F, Santonastaso M, Scarcelli V (2015) n-TiO2 and $\mathrm{CdCl} 2$ co-exposure to titanium dioxide nanoparticles and cadmium: Genomic, DNA and chromosomal damage evaluation in the marine fish European sea bass (Dicentrarchus labrax) Aquat Toxicol 168:72-77

Rahman Q, Lohani M, Dopp E, Pemsel H, Jonas L, Weiss DG, Schiffmann D (2002) Evidence that ultrafine titanium dioxide induces micronuclei and apoptosis in Syrian hamster embryo fibroblasts Environ Health Perspect 110:797-800

Ramsden C, Henry T, Handy R (2013) Sub-lethal effects of titanium dioxide nanoparticles on the physiology and reproduction of zebrafish Aquat Toxicol 126:404-413

Raza A, Javed S, Qureshi MZ, Khan MS (2017) Synthesis and study of catalytic application of 1-methionine protected gold nanoparticles Appl Nanosci 7:429-437 
321

322

323

324

325

326

327

328

329

330

331

332

333

334

335

336

337

338

339

340

341

342

343
Rocco L, Santonastaso M, Mottola F, Costagliola D, Suero T, Pacifico S, Stingo V (2015) Genotoxicity assessment of TiO2 nanoparticles in the teleost Danio rerio Ecotoxicol Environ Saf 113:223-230

Shakeel M, Jabeen F, Iqbal R, Chaudhry AS, Zafar S, Ali M, Khan MS, Khalid A, Shabbir S, Asghar MS (2018) Assessment of titanium dioxide nanoparticles (TiO 2-NPs) Induced hepatotoxicity and ameliorative effects of Cinnamomum cassia in Sprague-Dawley rats Biol Trace Elem Res 182:57-69

Shakeel M, Jabeen F, Shabbir S, Asghar MS, Khan MS, Chaudhry AS (2016) Toxicity of nano-titanium dioxide (TiO 2-NP) through various routes of exposure: a review Biol Trace Elem Res 172:1-36

Smith CJ, Shaw BJ, Handy RD (2007) Toxicity of single walled carbon nanotubes to rainbow trout,(Oncorhynchus mykiss): respiratory toxicity, organ pathologies, and other physiological effects Aquat Toxicol 82:94-109

Sohail M, Khan MN, Chaudhry AS, Qureshi NA (2016) Bioaccumulation of heavy metals and analysis of mineral element alongside proximate composition in foot, gills and mantle of freshwater mussels (Anodonta anatina) Rendiconti Lincei 27:687-696

Tang T, Zhang Z, Zhu X (2019) Toxic effects of TiO2 NPs on zebrafish Int J Environ Res Public Health 16:523

Vignardi CP, Hasue FM, Sartório PV, Cardoso CM, Machado AS, Passos MJ, Santos TC, Nucci JM, Hewer TL, Watanabe I-S (2015) Genotoxicity, potential cytotoxicity and cell uptake of titanium dioxide nanoparticles in the marine fish Trachinotus carolinus (Linnaeus, 1766) Aquat Toxicol 158:218-229

Wilhelm J (1990) Metabolic aspects of membrane lipid peroxidation Acta Universitatis Carolinae Medica Monographia 137:1-53

Xiong D, Fang T, Yu L, Sima X, Zhu W (2011) Effects of nano-scale TiO2, ZnO and their bulk counterparts on zebrafish: acute toxicity, oxidative stress and oxidative damage Sci Total Environ 409:1444-1452

Zhu X, Zhu L, Duan Z, Qi R, Li Y, Lang Y (2008) Comparative toxicity of several metal oxide nanoparticle aqueous suspensions to Zebrafish (Danio rerio) early developmental stage J Environ Sci Health A 43:278284 


\section{Figures}
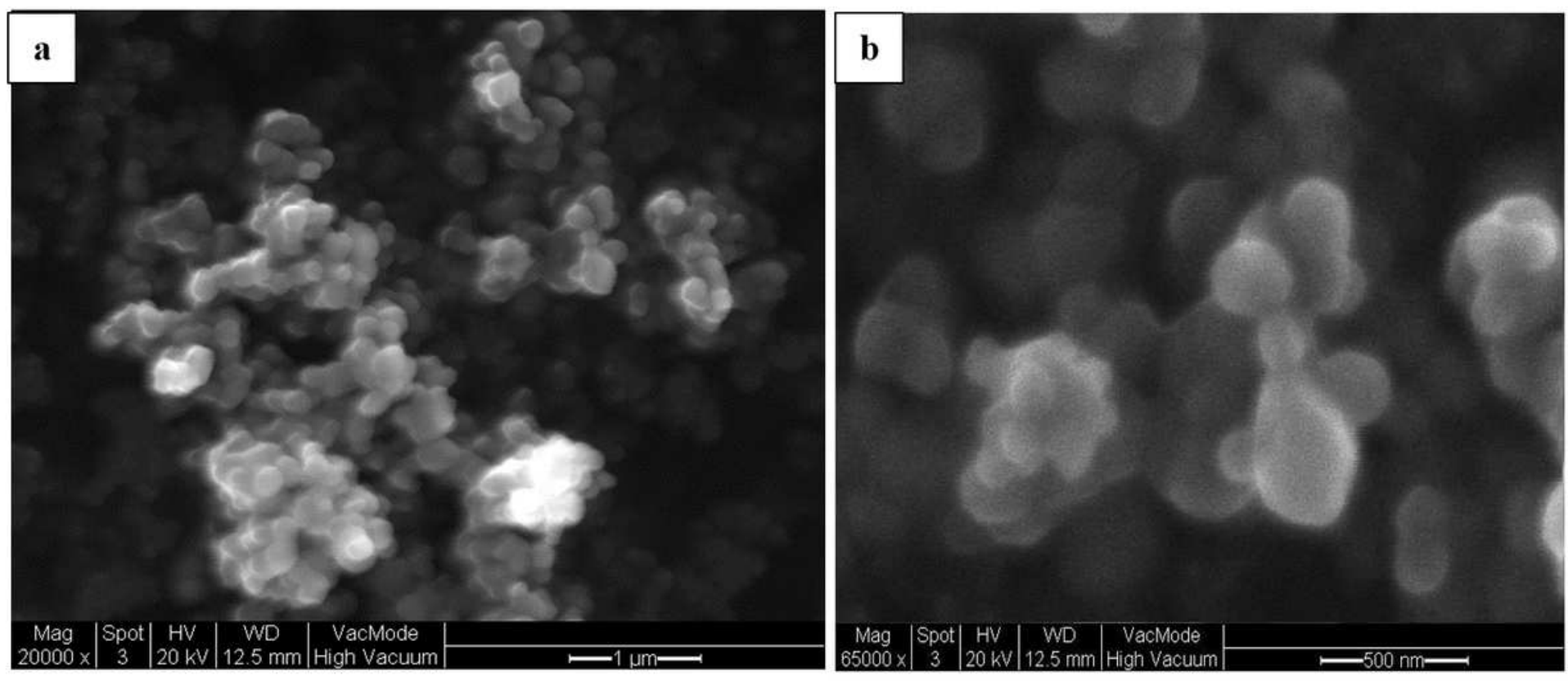

Figure 1

(a) and (b) showing the ESEM images of titanium dioxide nanoparticles (TiO2-NPs) at 20000 and 65000 magnifications 

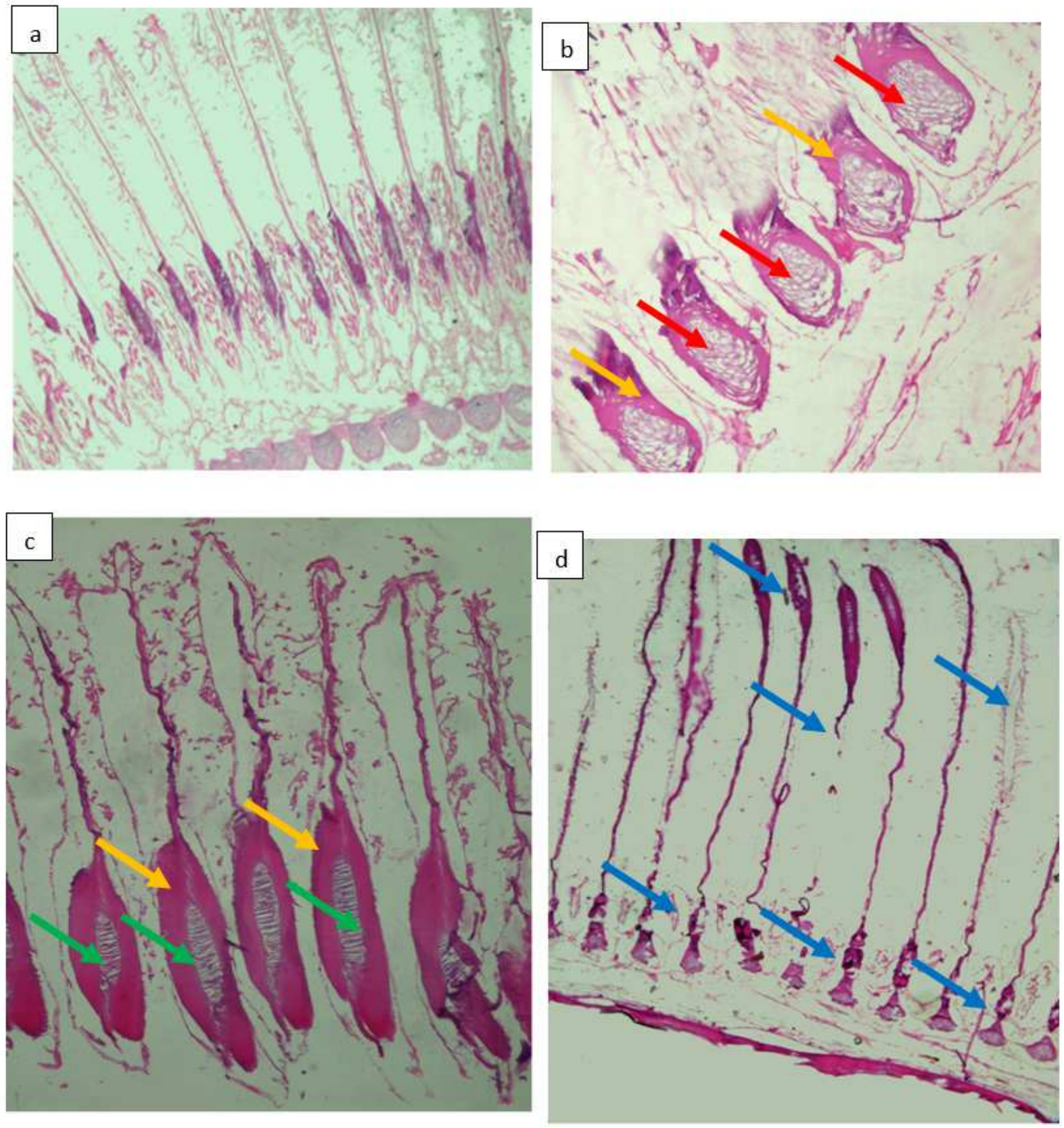

\section{Figure 2}

a-d Section of the gill of exposed fish. (a) The gill of control fish showing normal arrangement of primary and secondary gill lamellae. (c) to (d) The reference treated gill were showing hyperplasia (red arrows), fusion of gill lamellae (yellow arrows), rupturing of gill filaments (blue arrows) and thickening of primary and secondary gill lamellae (green arrows). 

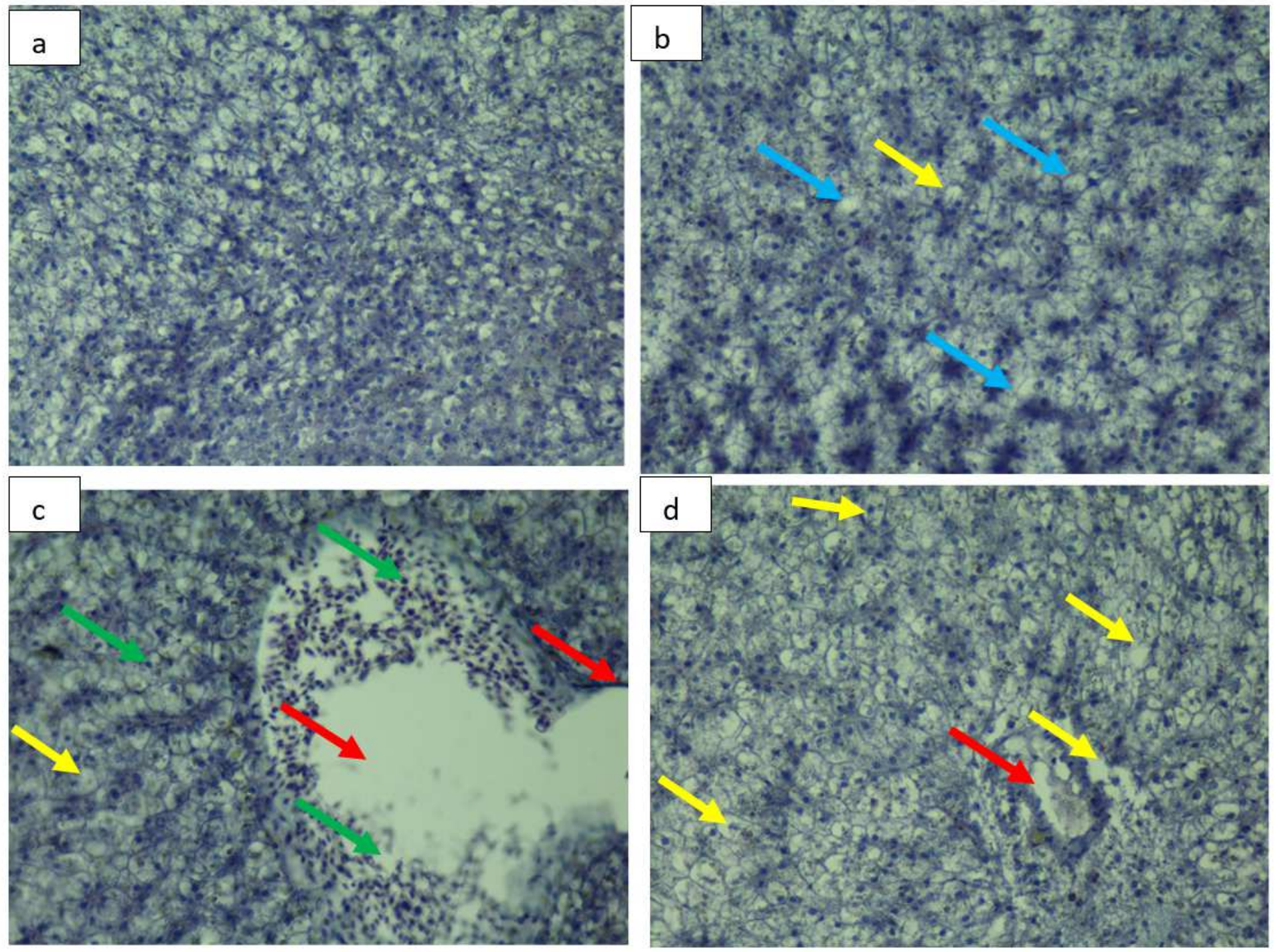

\section{Figure 3}

a-d Section of reference and treated fish liver. (a) The liver of control fish showing normal arrangement and distribution of hepatocytes. (c) to (d) Reference treated liver showing necrosis (blue arrows) and apoptosis (yellow arrows) with condensed nuclear bodies (green arrows) as indicated by black arrows, sinusoid spaces in relation to parenchyma (red arrows). 

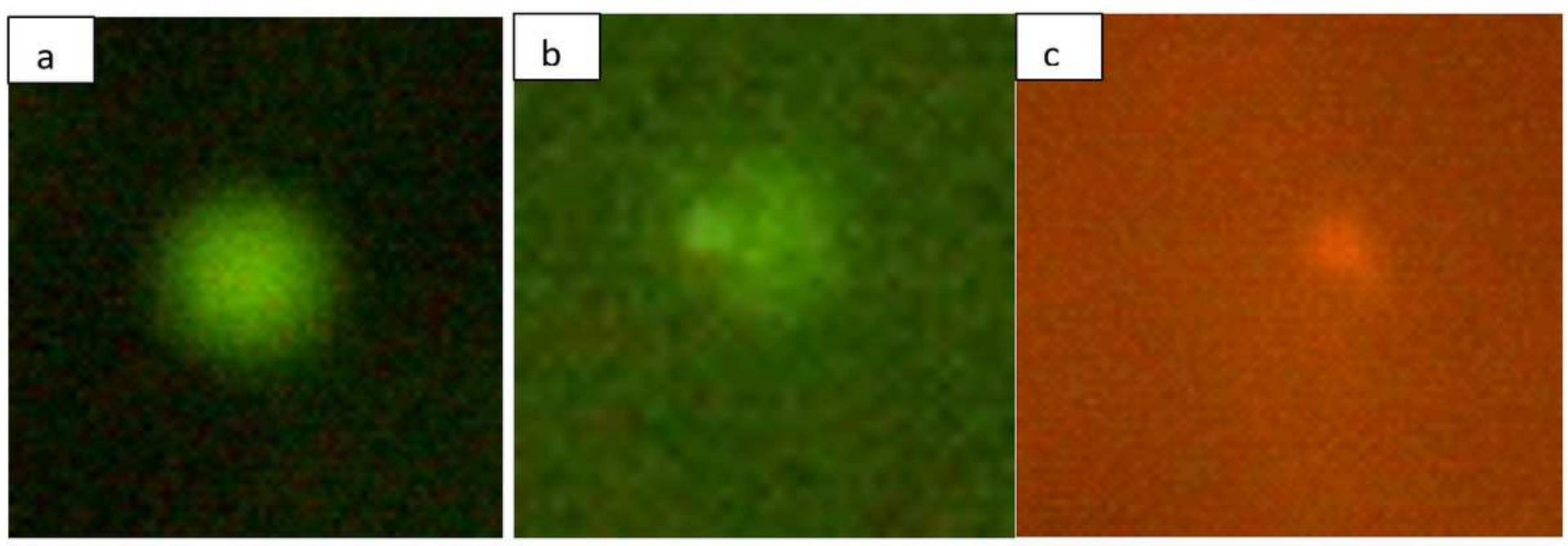

Figure 4

Evaluation of genotoxicity of TiO2-NPs in erythrocytes through Comet assay (a) normal erythrocytes (b) slightly damage erythrocyte (c) Large comet cell

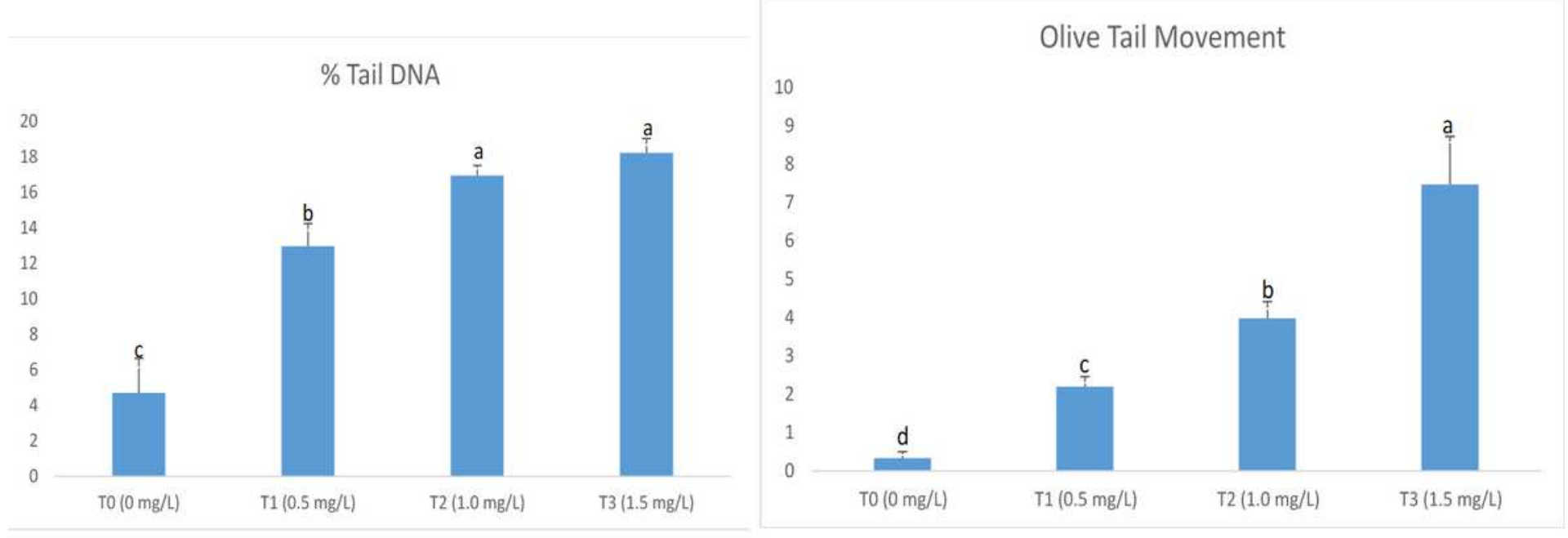

\section{Figure 5}

Genotoxicity of TiO2-NPs in erythrocytes. (a) Comets percentage of tail DNA and (b) olive tail movement Data are expressed as mean \pm S.D $(p<0.05)(N=10)$ 